Executive

Editors

Administrative Editor

Editorial Office

Book Reviews
BRYSON BROWN, University of Lethbridge

EMILY CARSON, McGill University

LUC FAUCHER, Université du Québec à Montréal

BRUCE HUNTER, University of Alberta

DAVID HUNTER, Ryerson University

MICHAEL HYMERS, Dalhousie University

RAHUL KUMAR, Queen's University

COLIN MACLEOD, University of Victoria

PATRICK RYSIEW, University of Victoria

AMY SCHMITTER, University of Alberta

WILLIAM SEAGER, University of Toronto

SARAH STROUD, McGill University

MICHAEL STINGL, University of Lethbridge

Editorial Board Coordinator, Secretary and Treasurer

MARDA SCHINDELER, Executive Secretary

Canadian Journal of Philosophy

University of Lethbridge

4401 University Drive

Lethbridge, Alberta T1K 3M4

Email: cjp@uleth.ca

BRUCE HUNTER, Book Review Editor

Department of Philosophy

University of Alberta

Edmonton, Alberta T6G 2E5

Subscriptions, Advertisements, Permissions:

University of Calgary Press

2500 University Drive N.W.

Calgary, Alberta T2N 1N4

Telephone: (403) 220-7736

Email: ucpmail@ucalgary.ca

The Canadian Journal of Philosophy is incorporated in Alberta and operated by the Board of Editors. It was founded in 1971 under the editorship of John King-Farlow, Kai Nielsen, T.M. Penelhum, and W.W. Rozeboom.

\title{
ISSN 0045-5091
}

Canada Post Publications Mail Agreement Number 40064590

(C2011 Canadian Journal of Philosophy 


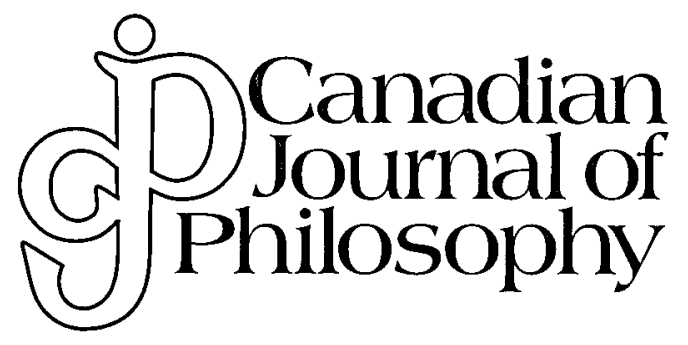


TABLE OF SELF VISITATION, TRAVELER TIME, CONTENTS AND COMPATIBLE PROPERTIES

John W. Carroll

ON THE THEORETICAL MOTIVATION FOR POSITING ETIOLOGICAL FUNCTIONS

Björn Brunnander

IMAGINABILITY, POSSIBILITY, AND THE

PUZZLE OF IMAGINATIVE RESISTANCE

Janet Levin

DESCRIPTION, DISAGREEMENT, AND

FICTIONAL NAMES

Peter Alward

PRACTICAL REASON AND THE

UNITY OF AGENCY

CRITICAL NOTICE OF CHRISTINE M. KORSGAARD SELF-CONSTITUTION: AGENCY, IDENTITY, AND INTEGRITY

Michael Garnett

CRITICAL NOTICE OF RICHARD GASKIN

THE UNITY OF THE PROPOSITION

Bernard Linsky

Notes on Contributors/Sur les Collaborateurs

Information for Authors/Avis aux Auteurs

Subscription Information/Abonnements

Other Business Information/

Services administratifs-détails supplementaires 
FROM THE EDITORIAL OFFICE
The Editorial Board thanks Sam Black for his years of service to the Journal, and welcomes Rahul Kumar as a new member of the Editorial Board.

This past year CJP received 217 papers, with an acceptance rate of $4.6 \%$.

Most papers are sent anonymously to two expert external referees. When papers are sent to referees, the Journal aims at a six month response time for the author. For papers not sent for external review, the Journal aims at a three month response time for authors.

All papers are given an initial anonymous review in the editorial office. Promising papers are sent to an editor in their area, who may then send them (anonymously) to two referees. Papers with two strong referees' reports and the endorsement of the editor are sent to the editorial board as a whole, still anonymously, for discussion and a vote on acceptance. The current backlog of accepted papers is currently about six months.

Because of the number of papers it receives, $C J P$ is normally able to consider papers of no longer than 10,000 words. Longer papers may be returned to authors with a suggestion to shorten them or to submit them elsewhere.

$C J P$ is now available through a variety of electronic aggregators, some for profit and some not for profit. In terms of revenue, it matters greatly to the Journal how we are accessed electronically through libraries, with nonprofit aggregators like Project Muse and JSTOR offering us the best revenue sharing arrangements.

In the future, it is our view that scholars and libraries will need to pay more attention to how they are receiving and using journals in electronic form, particularly independent journals like CJP.

$C J P$ is also available at its own website, on an open access model, but with a twenty-four month embargo on current content to protect our revenues from other sources:

http://www.canadianjournalofphilosophy.com

Almost all authors are now submitting their papers electronically. This enables us to process papers more quickly, within the constraints mentioned above. Papers should be sent to Marda Schindeler, the Journal's Executive Secretary, at cjp@uleth.ca, in either Word or WordPerfect (native and RFT file format), and formatted according to the Journal's directions for authors.

Michael Stingl

Administrative Editor 